\title{
ANALISA MAKRO EKONOMI PADA PERUSAHAAN PELAYARAN DI INDONESIA
}

\author{
R.A. Norromadani Yuniati \\ Politeknik Perkapalan Negeri Surabaya \\ norromadani.y@ppns.ac.id \\ Farizi Rachman \\ Politeknik Perkapalan Negeri Surabaya \\ farizirachman@ppns.ac.id \\ Ratri Wahyuning Purwitasari \\ Politeknik Perkapalan Negeri Surabaya \\ ratriprwta26@gmail.com
}

Abstract

Each country must pay attention to the money market or capital market to take advantage of internationalization opportunities and trade between countries in the Asian region, especially in the maritime sector. The success of the capital market in a country, especially in the maritime industry sector, is influenced by external circumstances such as macroeconomic and internal factors such as its performance. This study aims to determine the effect of macroeconomic factors on the abnormal return of shipping companies in Indonesia. Data analysis methods used to test hypotheses in research are using Multiple Linear Regression Analysis and Path Analysis. The determination of the sample in this study used a purposive sampling method. The result showed that ROE could not partially be an intervening variable between macroeconomics and abnormal return.

Keywords : Abnormal Return; Macroeconomics; Path Analysis; Return on Equity,

\section{PENDAHULUAN}

Efesiensi dan efektifitas pengambilan keputusan investasi merupakan sebuah kegiatan yang membutuhkan beberapa pertimbangan dan analisa yang akurat guna meminimalisir kesalahan yang terjadi. Seperti yang telah kita ketahui selama ini, bahwa oppourtunis merupakan sikap yang banyak digunakan oleh banyak investor dalam pengambilan keputusan investasi. Namun teknik analisa (teknikal, fundamental atau industri) terhadap faktor mikro dan makro ekonomi tidak kalah penting untuk diperhatikan. Faktor makro ekonomi telah banyak diteliti dan dikaji secara ilmiah. Hal itu membuktikan perannya pada kinerja pasar modal khususnya di Indonesia, sehingga banyak mendapatkan perhatian dari para pelaku pasar. Perubahan pada variabel makro ekonomi memiliki kecenderungan untuk memengaruhi pasar modal baik secara langsung maupun tidak langsung. Ketika terjadi perubahaan makroekonomi, para investor akan memperhitungkan dampaknya terhadap kinerja perusahaan beberapa tahun ke depan. Kemudian mengambil keputusan membeli, menjual, atau menahan instrument investasinya. Adapun indikator makro ekonomi yang dapat digunakan oleh investor sebagai dasar pengambilan keputusan antara lain PDB, inflasi, tingkat suku bunga, kurs rupiah, anggaran defisit, investasi swasta serta neraca perdagangan dan pembayaran (Tandelilin, 2010).

Indonesia termasuk salah satu negara berkembang di kawasan Asia. Indonesia terletak diantara dua samudera, Samudera Pasifik dan Hindia yang menjadikan Indonesia sebagai kawasan penghubung perekonomian antar negara-negara maju di dunia. Kekuatan ini menjadi salah satu potensi besar yang dimiliki untuk meningkatkan pertumbuhan perekonomian di Indonesia. Peran Pemerintah dalam pertumbuhan perekonomian di Indonesia cukup besar, terutama keterkaitannya dengan kebijakankebijakan yang mengatur indikator-indikator makro di atas dalam rangka menciptakan iklim investasi yang baik. Selain potensi perekonomian yang meningkat, Indonesia juga memiliki potensi besar di bidang maritim. Sebagai salah satu negara kepulauan terbesar di Asia, perairan Indonesia kaya akan sumber daya. Namun tidak bisa kita pungkiri bahwa iklim investasi di sektor industri tersebut 
Norromadani Yuniati, Farizi Rachman, Ratri Wahyuning Purwitasari. Analisa Makro Ekonomi pada Perusahaan pelayaran di Indonesia

dirasakan masih terkesan melambat. Tantangan industri ini juga tidak terlepas dari variabel faktor ekonomi secara makro seperti halnya suku bunga yang tinggi sementara margin profit pelayaran nasional yang masih relatif sedikit, pembebanan PPN (Pajak Pertambahan Nilai) atas pembelian BBM pelayaran dalam negeri, serta efisiensi biaya kepelabuhan (Maritim Expo, 2019).

Besarnya potensi maritim di Indonesia tidak menjadikan transaksi saham sektor transportasi laut di pasar modal tinggi. Jika dibandingkan dengan indsutri lain seperti pada indsutri barang konsumen yang memiliki indeks sebesar 2,052.654 per 2019 dan tingkat pengembalian hingga $205.77 \%$ serta industri sektor keuangan yang memiliki indeks sebesar 1,354.661 per 2019 dan tingkat pengembalian sebesar $349.42 \%$. Sementara indeks pada sektor transportasi hanya sebesar 1,137.544 dengan tingkat pengembalian 56.14\% (BEI, 2019). Kenyataan tersebut masih menjadi tugas besar pemerintah, para pelaku ekonomi khususnya investor pasar modal serta dunia akademisi untuk terus mengembangkan upaya-upaya meningkatkan minat investasi masyarakat khususnya di bidang maritim melalui faktor ekonomi makro seperti yang akan dikaji lebih dalam dalam permasalahan penelitian ini.

Penelitian ini mengkaji permasalahan terkait pengaruh indikator-indikator dalam variabel makro ekonomi terhadap abnormal return secara tidak langsung melalui ROE sebagai variabel interveningnya. Adapun indikator pengukuran variabel makro ekonomi yang digunakan mencakup inflasi, PDB, bunga, dan kurs mata uang. Pengujian dan analisa akan dirinci untuk masing-masing indikator variabel makro ekonomi beserta pengaruhnya dengan dan tanpa menggunakan variabel intervening tersebut sehingga lebih komprehensif.

\section{KAJIAN PUSTAKA DAN PENGEMBANGAN HIPOTESIS}

\section{Makroekonomi}

Pasar modal mencerminkan apa yang terjadi pada perekonomian makro karena nilai investasi ditentukan oleh aliran kas yang diharapkan serta tingkat return yang disyaratkan atas investasi tersebut, dan kedua faktor tersebut sangat dipengaruhi oleh perubahan lingkungan ekonomi makro (Tandelilin, 2010). Fluktuasi yang terjadi di pasar modal akan terkait dengan perubahan yang terjadi pada berbagai variabel ekonomi makro. Investor harus memperhatikan beberapa indikator ekonomi makro yang bisa membantunya dalam memahami dan meramalkan kondisi ekonomi makro. Produk Domestik Bruto adalah nilai pasar seluruh barang dan jasa akhir yang diproduksi di suatu negara pada periode tertentu (Mankiw, 2014). PDB juga dapat diartikan sebagai nilai keseluruhan semua barang dan jasa yang diproduksi di dalam wilayah tersebut dalam jangka waktu tertentu (biasanya per tahun) (Sukirno, 2010). Inflasi adalah keadaan dimana terjadinya peningkatan harga produk-produk secara keseluruhan sehingga terjadi penurunan daya beli uang (Tandelilin, 2010). Peningkatan inflasi secara relatif merupakan sinyal negatif bagi pemodal di pasar modal. Tingkat suku bunga (Boediono, 2014) adalah harga dari penggunaan dana investasi (lonable funds). Tingkat suku bunga merupakan salah satu indikator dalam menentukan apakah seseorang akan melakukan investasi atau menabung. Tingkat bunga yang tinggi merupakan sinyal negatif terhadap harga saham. Tingkat suku bunga yang meningkat akan menyebabkan peningkatan suku bunga yang disyaratkan atas investasi pada suatu saham. Nilai tukar atau kurs antara dua negara adalah tingkat harga yang disepakati kedua negara untuk melakukan perdagangan (Apriyani, Rindayati, \& Wiliasih, 2015). Menguatnya kurs domestik terhadap mata uang asing merupakan sinyal positif bagi perekonomian.

\section{Return on Equity}

ROE atau Return on Equity dapat digunakan untuk mengukur kemampuan perusahaan dalam menghasilkan laba bersih dari modal yang digunakan oleh perusahaan. ROE juga dapat menunjukkan rentabilitas modal sendiri atau yang sering disebut rentabilitas usaha. Untuk mengetahui ROE dapat membagi laba bersih setelah pajak dengan total ekuitas yang dimiliki perusahaan.

\section{Abnormal Return}

Abnormal Return merupakah selisih antara tingkat keuntungan aktual dengan tingkat keuntungan yang diharapkan. Return aktual atau return yang sesungguhnnya adalah return yang terjadi pada saat itu yang merupakan selisih harga saham saat itu dengan harga saham sebelumnya. Sementara itu 
expected return atau return harapan merupakan return yang harus diestimasi. Terdapat beberapa model untuk menghitung return harapan yaitu mean adjusted return, market adjusted return, dan market model return. Sementara untuk penelitian ini menggunakan pendekatan market adjusted return.

\section{Hubungan antar Variabel}

Kenaikan inflasi akan menurunkan capital gain dan menyebabkan berkurangnya keuntungan yang diperoleh investor. Resiko yang akan dihadapi investor menjadi lebih besar jika tetap berinvestasi dalam bentuk saham, sehingga mengakibatkan permintaan terhadap saham akan turun (Ishomuddin, 2010). Apabila permintaan saham turun, maka harga saham akan ikut menurun sehingga return yang akan diperoleh investor berkurang. Tingkat suku bunga adalah harga dari penggunan dana investasi (loanable funds), tingkat suku bunga merupakan salah satu indikator dalam menentukan apakah seseorang akan melakukan investasi atau menabung (Boediono, 2014). Perubahan suku bunga bisa memengaruhi variabilitas return suatu investasi. Perubahan suku bunga akan memengaruhi harga saham secara terbalik, ceteris paribus, artinya jika suku bunga meningkat maka harga saham akan turun (Tandelilin, 2010). Investor asing menanamkan dananya dalam bentuk saham. Investor masuk karena adanya pertumbuhan ekonomi. Pertumbuhan ekonomi suatu negara salah satunya dapat dicerminkan melalui jumlah PDB yang diperoleh negara tersebut. Jika pertumbuhan ekonomi meningkat, tentu saja akan meningkatkan daya beli masyarakat dan pola investasinya, sehingga hal tesebut akan mendorong perusahaan untuk meningkatkan penjualan maupun labanya (Putra, I.N.S.A, dan I.G.A.N, 2016). ROE dalam hal ini adalah rasio yang dapat digunakan untuk mengukur kemampuan perusahaan dalam menghasilkan laba bersih dari modal yang digunakan oleh perusahaan. Semakin tinggi angka ROE tentunya menunjukkan keadaan finansial perusahaan yang semakin baik. Apabila ROE yang dihasilkan perusahaan meningkat maka tingkat pengembalian yang diterima investor juga akan meningkat karena profit perusahaan yang juga meningkat.

$\mathrm{H}$ : Variabel makroekonomi secara parsial berpengaruh tidak langsung terhadap abnormal return saham melalui ROE.

\section{METODE PENELITIAN}

Penelitian ini menggunakan model cross section analysis, melalui pengamatan aktifitas pergerakan kinerja pasar saham shipping company di Indonesia yang tercatat sebagi perusahaan go public mulai 2014 sampai 2018. Teknik sampling menggunakan purposive sampling. dengan kriteria: (1) Shipping company yang memiliki performa baik di pasar modal Indonesia (BEI) periode 2014-2018; (2) Belum pernah mengalami delisting maupun relisting di BEI pada periode 2014-2018, dan (3) Melakukan IPO pada kisaran tahun 2011-2013. Berdasarkan kriteria tersebut diperoleh 3 perusahaan sampel yakni PT. Mitrabahtera Segara Sejati Tbk, PT. Buana Lintas Lautan Tbk dan PT. Logindo Samudra Makmur Tbk. Berdasarkan segi eksplanasinya, penelitian ini tergolong penelitian asosiatif yaitu mengetahui pengaruh ataupun juga hubungan antara dua variabel atau lebih.

Jenis data yang dikumpulkan merupakan data kuantitatif. Data sekunder berasal dari perusahaan yang melakukan penawaran umum perdana pada periode 2014-2018 dari situs Bursa Efek Indonesia, Official Website perusahaan, dan yahoo finance. Selain itu, sumber informasi lain yang digunakan dalam penelitian ini seperti inflasi, tingkat suku bunga, tingkat nilai tukar dan produk domestik bruto periode 2014 sampai dengan 2018 berasal dari situs pemerintah Indonesia, IMF, World Bank, Bank Indonesia. Adapun teknik pengumpulan data dilakukan dengan studi pustaka dan dokumentasi. Analisis data menggunakan regresi linear berganda seperti pada rumus (1)

$$
A R=\beta_{0}+\beta_{1} I N F+\beta_{2} R A T E+\beta_{3} P D B+\beta_{4} K U R S+\beta_{5} R O E+\mathrm{e}
$$

Sebelum analisis regresi, dilakukan uji asumsi klasik. Tahap pengujian hipotesis, dilakukan uji F, uji t, dan koefisien determinasi.Selanjutnya menggunakan path analysis. 
Norromadani Yuniati, Farizi Rachman, Ratri Wahyuning Purwitasari. Analisa Makro Ekonomi pada Perusahaan pelayaran di Indonesia

\section{HASIL DAN PEMBAHASAN}

\section{Uji Asumsi Klasik}

Berdasarkan hasil Uji Normalitas dengan metode One Sample Kolmogorovsmirnov menunjukan bahwa hasil uji dalam model ini memiliki nilai Asymp.Sig (2-tailed) sebesar 0.200 di atas 0.05 dengan tingkat signifikansi $\alpha=5 \%$, hal ini berarti data berdistribusi dengan normal. Uji Multikolinieritas menunjukan bahwa pada variabel inflasi, PDB, suku bunga, tingkat nilai tukar, dan ROE terhadap abnormal return masing-masing memiliki nilai Tolerance lebih dari 0.10 dan nilai Variance Inflation Factor (VIF) kurang dari 10, hal ini berarti bahwa tidak terjadi multikolinieritas antara variabel independen dengan variabel dependen. Hasil uji heteroskedastisitas menunjukkan hasil variabel independen masing-masing mempunyai nilai Sig > 0.05, sehingga tidak ada variabel independen yang signifikan memengaruhi variabel dependen absolut secara statistik. Hasil Uji Autokorelasi dalam penelitian ini memiliki nilai Durbin-Watson sebesar 2.098 berada diantara nilai du dan 4-du, sehingga dapat ditarik kesimpulan bahwa data dalam persamaan yang digunakan digunakan dalam penelitian ini bebas dari gejala autokorelasi.

\section{Uji Koefisien Determinasi $\left(\mathbf{R}^{2}\right)$}

Pada uji koefisien determinasi $\left(\mathrm{R}^{2}\right)$ diperoleh hasil nilai $\mathrm{R}$ Square sebesar 0.293. Hal ini berarti bahwa pada penelitian ini variabel independen yaitu inflasi, PDB, tingkat suku bunga, tingkat nilai tukar (kurs), dan ROE memengaruhi variabel dependennya yaitu abnormal return sebesar $29.3 \%$, sedangkan sisanya sebesar $70.7 \%$ dipengaruhi oleh variabel lain yang tidak dimasukkan ke dalam penelitian ini. Rendahnya nilai R Square karena banyaknya faktor lain yang memengaruhi pergerakan abnormal return suatu perusahaan.

\section{Uji Hipotesis}

Tabel 1

HASIL UJI HIPOTESIS

\begin{tabular}{|c|c|c|c|c|}
\hline & Model & $\begin{array}{c}\text { Coefficientsa } \\
\text { Standardized Coefficients } \\
\text { Beta }\end{array}$ & $\mathrm{T}$ & Sig. \\
\hline \multirow{8}{*}{1} & (Constant) & & 3.286 & 0.002 \\
\hline & INFLASI & -0.226 & -1.084 & 0.283 \\
\hline & PDB & 0.023 & 0.102 & 0.919 \\
\hline & SUKU BUNGA & -0.384 & -1.586 & 0.119 \\
\hline & TK NILAI TUKAR & -0.398 & -2.465 & 0.017 \\
\hline & ROE & 0.142 & 1.168 & 0.248 \\
\hline & & $\mathrm{F}$ & & 4.473 \\
\hline & & Sig F & & $.002 \mathrm{~b}$ \\
\hline
\end{tabular}

a Dependent Variable: ABNORMAL RETURN

Sumber : olah data SPSS, 2020

Berdasarkan tabel 1, didapatkan persamaan regresi linier berganda sebagai berikut

$A R=a-0.226 I N F+0.023 P D B-0.384 S B-0.398 K U R S+0.142 R O E+\mathrm{e}$.

Berdasarkan persamaan model regresi dan hasil uji hipotesis tersebut, dapat ditinjau seberapa besar pengaruh masing-masing variabel independen terhadap variabel dependen. Berikut adalah penjelasan mengenai pengaruh tiap variabel independen.

Nilai koefisien inflasi sebesar -0.226 berarti inflasi berhubungan negatif dengan abnormal return saham sampel penelitian. Hasil uji t menunjukkan nilai signifikansi 0.283 berada di atas derajat kesalahan yaitu 0.05 . Hal ini berarti inflasi tidak berpengaruh signifikan terhadap abnormal return. 
Nilai koefisien PDB terhadap abnormal return sebesar 0.023. Hal ini menunjukkan hubungan yang positif antara kedua variabel tersebut dengan cateris paribus. Hasil uji t menunjukkan nilai signifikansi 0.919 berada di atas derajat kesalahan yaitu 0.05 , berarti PDB mempunyai hubungan yang positif tetapi tidak berpengaruh signifikan terhadap abnormal return.

Nilai koefisien tingkat suku bunga sebesar -0.384 berarti tingkat suku bunga berhubungan negatif dengan abnormal return saham sampel penelitian Hal ini berarti apabila nilai tingkat suku bunga mengalami kenaikan satu satuan maka nilai abnormal return akan mengalami penurunan sebesar 0.384 kali dengan asumsi keadaan semua variabel dianggap bernilai konstan, begitu sebaliknya. Hasil uji t menunjukkan nilai signifikansi 0.119 berada di atas derajat kesalahan yaitu 0.05 , berarti tingkat suku bunga mempunyai hubungan yang negatif tetapi tidak berpengaruh signifikan terhadap abnormal return.

Nilai koefisien tingkat nilai tukar sebesar -0.398. Hal ini berarti terdapat hubungan negatif antara kedua variabel tersebut. Hasil uji t menunjukkan nilai signifikansi sebesar 0.017 yang berada dibawah derajat kesalahan yaitu 0.05 , berarti tingkat nilai tukar berpengaruh signifikan negatif terhadap abnormal return.

Nilai koefisien ROE sebesar 0.142; hal ini berarti apabila nilai ROE mengalami kenaikan satu satuan maka nilai abnormal return akan mengalami kenaikan sebesar 0.142 kali dengan asumsi keadaan semua variabel dianggap bernilai konstan, begitu sebaliknya. Hasil uji t menunjukkan nilai signifikansi 0.248 berada di atas derajat kesalahan yaitu 0.05 , berarti ROE mempunyai hubungan yang positif tetapi tidak berpengaruh signifikan terhadap abnormal return.

\section{Path Analysis}

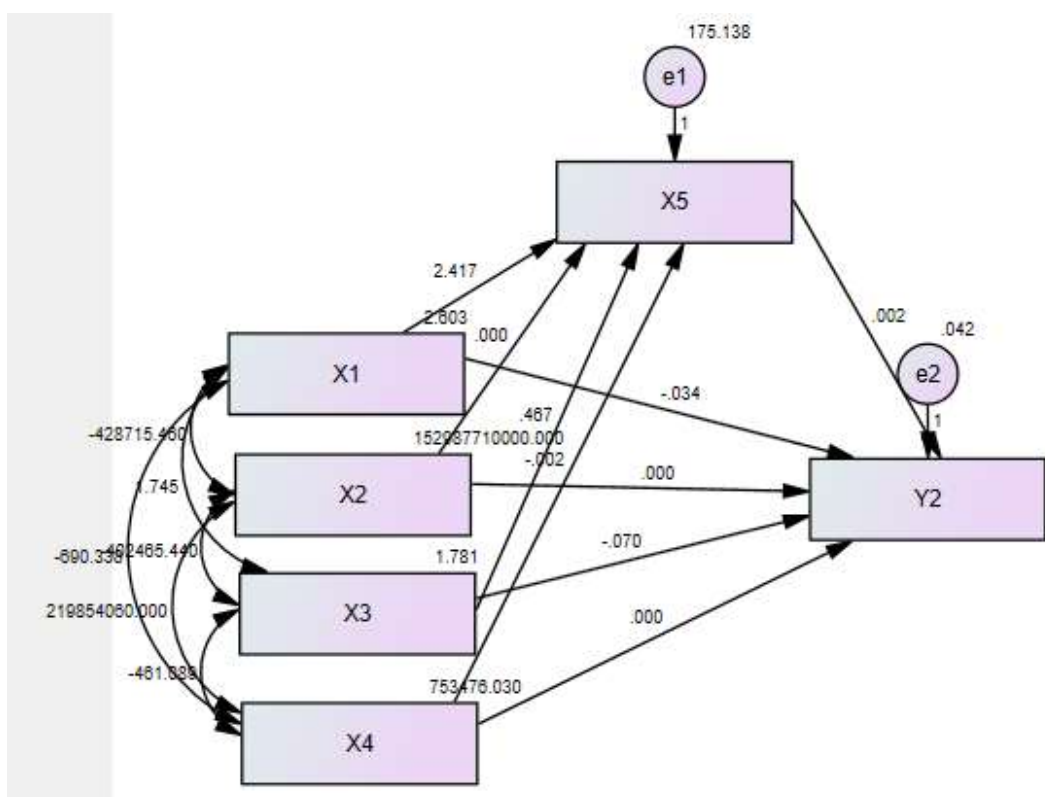

Sumber : olahan data AMOs, 2020

\section{Gambar 1 DIAGRAM JALUR}


Norromadani Yuniati, Farizi Rachman, Ratri Wahyuning Purwitasari. Analisa Makro Ekonomi pada Perusahaan pelayaran di Indonesia

Tabel 2

HASIL UJI PATH ANALYSIS

\begin{tabular}{lccccc}
\hline \multicolumn{2}{c}{ Variabel } & Estimate & Direct & Indirect & $\mathrm{P}$ \\
\hline $\mathrm{ROE}$ & $\leftarrow$ INFLASI & 0.277 & 0.277 & 0 & 0.209 \\
$\mathrm{ROE}$ & $\leftarrow$ PDB & 0.08 & 0.08 & 0 & 0.735 \\
$\mathrm{ROE} \leftarrow$ BI RATE & 0.044 & 0.044 & 0 & 0.864 \\
$\mathrm{ROE}$ & $\leftarrow$ KURS & -0.144 & -0.144 & 0 & 0.402 \\
$\mathrm{AR}$ & $\leftarrow$ ROE & 0.142 & 0.142 & 0 & 0.222 \\
$\mathrm{AR}$ & $\leftarrow$ INFLASI & -0.226 & -0.226 & 0.039 & 0.257 \\
$\mathrm{AR}$ & $\leftarrow$ PDB & 0.023 & 0.023 & 0.011 & 0.915 \\
$\mathrm{AR}$ & $\leftarrow$ BI RATE & -0.384 & -0.384 & 0.006 & 0.097 \\
$\mathrm{AR}$ & $\leftarrow$ KURS & -0.398 & -0.398 & -0.02 & 0.01 \\
\hline
\end{tabular}

Sumber : olah data AMOs, 2020

Pada software uji yang digunakan yaitu AMOS tidak memberikan signifikansi hubungan tidak langsung antara variabel. Dalam hal ini perlu dilakukan uji sobel test. Tabel 3 merupakan hasil uji sobel test.

Tabel 3

HASIL UJI SOBEL TEST

\begin{tabular}{lc}
\hline \multicolumn{1}{c}{ Pengaruh Tidak Langsung } & Z Sobel \\
\hline NFLASI - ROE - AR & 0.78 \\
PDB - ROE - AR & 0.00 \\
BI RATE- ROE - AR & 0.17 \\
KURS - ROE - AR & -0.55 \\
\hline
\end{tabular}

Sumber : olah data AMOs, 2020

Berdasarkan tabel 2 masing-masing variabel independen memiliki pengaruh yang berbeda terhadap variabel intervening yaitu ROE dan variabel dependen yaitu abnormal return. Berikut akan dijelaskan masing masing pengaruh langsung dan tidak langsung antara variabel independen, intervening, dan dependen.

Nilai koefisien jalur inflasi terhadap abnormal return sebesar -0.226 dengan nilai signifikansi sebesar 0.257 , hal ini berarti inflasi tidak berpengaruh signifikan secara langsung terhadap abnormal retun secara langsung. Sementara untuk mengetahui pengaruh inflasi terhadap abnormal return secara tidak langsung melalui ROE dapat ditinjau dari hasil uji sobel test. Nilai z sobel pada jalur pengaruh inflasi terhadap abnormal return melalui ROE yaitu sebesar 0.78 yang berada di bawah angka standar uji diterima yaitu 1.96 maka dalam model ini ROE tidak mampu memediasi pengaruh variabel inflasi terhadap abnormal return.

Nilai koefisien jalur PDB terhadap abnormal return sebesar 0.023 dengan signifikansi sebesar 0.915 , hal ini berarti PDB juga tidak berpengaruh signifikan terhadap abnormal return secara langsung. Sementara untuk mengetahui pengaruh PDB terhadap abnormal return melalui ROE dapat ditinjau dari hasil uji sobel test. Nilai z sobel pada jalur pengaruh PDB terhadap abnormal return melalui ROE yaitu sebesar 0.00 yang berada di bawah angka standar uji diterima yaitu 1.96 maka dalam model ini ROE tidak mampu memediasi pengaruh variabel PDB terhadap abnormal return.

Nilai koefisien jalur Tingkat suku bunga terhadap abnormal return sebesar -0.384 dengan signifikansi sebesar 0.097, hal ini berarti tingkat suku bunga juga tidak berpengaruh signifikan terhadap abnormal return secara langsung. Sementara untuk mengetahui pengaruh tingkat suku bunga terhadap abnormal return melalui ROE dapat ditinjau dari hasil uji sobel test. Nilai z sobel pada jalur pengaruh tingkat 
suku bunga terhadap abnormal return melalui ROE yaitu sebesar 0.17 yang berada di bawah angka standar uji diterima yaitu 1.96 maka dalam model ini ROE tidak mampu memediasi pengaruh variabel tingkat suku bunga terhadap abnormal return.

Nilai koefisien jalur tingkat nilai tukar terhadap abnormal return sebesar -0.398 dengan signifikansi sebesar 0.01, hal ini berarti tingkat nilai tukar berpengaruh signifikan terhadap abnormal return secara langsung. Sementara untuk mengetahui pengaruh tingkat nilai tukar terhadap abnormal return melalui ROE dapat ditinjau dari hasil uji sobel test. Nilai z sobel pada jalur pengaruh tingkat nilai tukar terhadap abnormal return melalui ROE yaitu sebesar -0.55 yang berada di bawah angka standar uji diterima yaitu 1.96 maka dalam model ini ROE tidak mampu memediasi pengaruh variabel tingkat nilai tukar terhadap abnormal return.

\section{Pengaruh Inflasi terhadap Abnormal Return}

Hasil menunjukkan bahwa inflasi tidak berpengaruh signifikan terhadap abnormal return karena inflasi bukan satu-satunya faktor yang dapat memengaruhi pergerakan abnormal return secara langsung. Hal ini juga dapat terjadi karena tingkat inflasi di Indonesia selama periode pengamatan masih dalam batas wajar serta kondisi ekonomi tidak dalam masa krisis seperti yang dapat ditinjau dari hasil perhitungan statistik deskriptif menunjukkan sebaran data inflasi berdistribusi dengan baik dan tidak terdapat kesenjangan nilai inflasi yang besar selama periode pengamatan, sehingga investor masih dapat mentolerir angka tersebut dan tidak berdampak pada pergerakan nilai abnormal return sahamnya.

Selain itu return saham juga dapat disebabkan oleh faktor lain yaitu faktor internal seperti kebijakan perusahaan itu sendiri (Afiyati, 2016). Walaupun inflasi tidak berpengaruh secara signifikan, tetapi inflasi mempunyai hubungan negatif terhadap abnormal return. Hubungan negatif ini sejalan dengan teori (Tandelilin, 2010) yang mengatakan bahwa adanya peningkatan inflasi merupakan sinyal negatif bagi investor. Dengan adanya peningkatan inflasi, kemampuan masyarakat terutama yang berpendapatan tetap dalam melakukan transaksi jual-beli akan menurun (Kementerian Keuangan Republik Indonesia, n.d.). Selain itu dari sisi perusahaan adanya peningkatan inflasi akan meningkatkan harga bahan baku dan meningkatkan biaya produksi. Hal ini menyebabkan harga produk akan meningkat di pasaran dan tingkat penjualan menurun sehingga laba perusahaan akan menurun dan memengaruhi performa harga saham di pasar modal. Hal ini erat kaitannya dengan pembagian deviden perusahaan di periode berikutnya karena keputusan kebijakan deviden salah satunya bergantung pada perolehan laba bersih perusahaan.

Inflasi merupakan sinyal negatif bagi investor karena inflasi dapat menurunkan daya beli sehingga tingkat pendapatan riil yang akan diterima oleh investor akan berkurang dan return yang didapatkan juga menurun. Apabila return yang diterima lebih sedikit daripada return yang diharapkan maka nilai abnormal return juga akan mengecil. Hasil penelitian ini sejalan dengan penelitian yang dilakukan oleh (Afiyati, 2016) dan (Wahyuningsih, Andini, \& Suprijanto, 2018) yang menyatakan bahwa inflasi berpengaruh negatif tetapi tidak signifikan terhadap return saham. Tetapi hasil penelitian ini tidak sejalan dengan penelitian yang dilakukan oleh (Jumiati, 2019), (Kurniasari, Wiratno, \& Yusuf, 2018), dan (Hidayat, Setyadi, \& Azis, 2017) yang menemukan bahwa inflasi berpengaruh negatif dan signifikan terhadap abnormal return, perbedaan objek dan periode penelitian dapat menyebabkan perbedaan hasil penelitian.

\section{Pengaruh PDB terhadap Abnormal Return}

Terdapat hubungan yang positif antara PDB dan abnormal return dalam kondisi cateris paribus. Hasil uji t menunjukkan PDB mempunyai hubungan yang positif tetapi tidak berpengaruh signifikan terhadap abnormal return. PDB yang tidak berpengaruh secara langsung terhadap abnormal return dapat disebabkan oleh beberapa faktor. Peningkatan PDB tidak menjamin adanya peningkatan pendapatan perkapita, karena perkembangan investasi di bidang riil tidak diikuti oleh perkembangan investasi di pasar modal (Kewal, 2012). Perbedaan perkembangan investasi di sektor riil tidak selalu sejalan dengan perkembangan investasi dalam instrument keuangan di pasar modal. Sedangkan 
Norromadani Yuniati, Farizi Rachman, Ratri Wahyuning Purwitasari. Analisa Makro Ekonomi pada Perusahaan pelayaran di Indonesia

indikator pengukuran PDB dalam makro ekonomi erat kaitannya dengan konsumsi produk pada perusahaan seperti yang dikemukanan oleh Mayfi, 2014 yang mengatakan bahwa peningkatan PDB suatu negara hanya berpengaruh secara langsung pada konsumsi produk suatu perusahaan, sehingga hal tersebut tidak dapat memengaruhi peningkatan harga saham secara langsung.

Walaupun PDB tidak berpengaruh secara langsung terhadap abnormal return pada penelitian ini, tetapi PDB mempunyai hubungan positif terhadap abnormal return yang tercemin dari koefisien regresi yang bernilai positif. Hubungan positif tersebut dikatakan dalam teori bahwa meningkatnya jumlah PDB akan memberikan efek positif terhadap investasi di pasar modal (Tandelilin, 2010). Meningkatnya jumlah PDB di suatu negara, berarti terjadi peningkatan daya beli oleh masyarakat. Namun terjadinya peningkatan daya beli tersebut memerlukan kajian lebih mendalam tentang kelompok produk yang dimaksud. Hail ini sejalan dengan penelitian yang dilakukan oleh (Putra, I.N.S.A, dan I.G.A.N, 2016), (Nidya \& Mawardi, 2018), dan (Sinaga \& Triaryati, 2014) yang menemukan bahwa PDB berpengaruh positif tidak signifikan terhadap return saham. Tetapi tidak sejalan dengan penelitian yang dilakukan oleh (Made Satria, 2016) yang menemukan bahwa PDB memiliki pengaruh negatif terhadap return saham.

\section{Pengaruh Tingkat Suku Bunga terhadap Abnormal Return}

Ttingkat suku bunga berhubungan negatif dengan abnormal return saham sampel penelitian. Hasil uji t menunjukkan tingkat suku bunga mempunyai hubungan yang negatif tetapi tidak berpengaruh signifikan terhadap abnormal return. Hal seperti ini dapat terjadi karena beberapa faktor. Kenaikan pada tingkat singkat bunga akan berpengaruh negatif terhadap return saham (Tandelilin, 2010). Apabila suku bunga mengalami kenaikan, akan berakibat terjadi penurunan harga saham sehingga ekspektasi dari return yang diterima tidak sesuai dengan kenyataan, sehingga investor akan lebih memilih untuk berinvestasi dalam bentuk selain saham seperti deposito atau tabungan. Hal ini sejalan dengan teori yang mengatakan perubahan suku bunga akan memengaruhi harga saham secara ceteris paribus, jika suku bunga naik maka return investasi yang terkait dengan suku bunga seperti obligasi dan deposito juga akan naik, investor akan lebih memilih mengalihkan dananya pada instrumen yang memberikan tingkat return yang tinggi dengan resiko yang lebih rendah daripada saham (Tandelilin, 2010).

Kenaikan suku bunga juga dapat menurunkan nilai sekarang pendapatan dividen di masa yang akan datang dan menurunkan harga saham (Suriyani \& Sudiartha, 2018). Nilai abnormal return yang negatif seperti pada hasil uji statistik deskriptif juga membuktikan bahwa akibat dari kenaikan tingkat suku bunga, return yang diterima oleh investor akan lebih kecil daripada return yang diharapkan. Tingkat suku bunga Bank Indonesia yang cenderung meningkat selama periode penelitian, juga memengaruhi perilaku investor dalam berinvestasi saham. Seperti pada penjelasan sebelumnya, tidak signifikannya hasil uji pengaruh antara tingkat suku bunga terhadap abnormal return karena banyaknya faktor lain (yang tidak diteliti dalam penelitian ini) yang dapat memengaruhi pergerakan abnormal return sebuah instrument investasi, serta diduga karena jumlah sampel yang digunakan dalam penelitian ini tidak cukup mewakili kondisi pasar modal Indonesia. Hasil penelitian ini bertentangan dengan penelitian yang dilakukan oleh (Made Satria, 2016) dan (Suriyani \& Sudiartha, 2018) yang menemukan bahwa tingkat suku bunga berpengaruh positif terhadap return saham. Tetapi hasil dari penelitian ini sejalan dengan penelitian yang dilakukan oleh (Jumiati, 2019) dan (Afifah, Fathoni, \& Amboningtyas, 2017) yang menemukan bahwa tingkat suku bunga berpengaruh negatif terhadap return saham.

\section{Pengaruh Tingkat Nilai Tukar terhadap Abnormal Return}

Hasil uji t menunjukkan tingkat nilai tukar berpengaruh signifikan negatif terhadap abnormal return. Nilai tukar mata uang dapat digunakan dalam aktivitas perekonomian seperti investasi dan transaksi perdagangan Internasional. Mata uang domestik yang mengalami depresiasi menandakan mata uang domestik tersebut menguat, dan sebaliknya apabila tingkat nilai tukar mengalami kenaikan 1 Rupiah berarti mata uang domestik melemah terhadap mata uang asing. (Pujawati, Wiksuana, Gede, \& Artini, 2015) dalam penelitiannya mengatakan sebuah teori bahwa depresiasi nilai mata uang Rupiah terhadap Dollar akan memberikan pengaruh yang menguntungkan bagi perusahaan. 
Depresiasi nilai tukar mata uang domestik terhadap mata uang asing dapat meningkatkan volume ekspor sehingga akan menambah profitabilitas sebuah perusahaan. Apabila kinerja perusahaan tersebut baik maka harga saham akan meningkat dan berpengaruh terhadap return yang akan didapatkan oleh investor. Semakin rendah nilai tukar Rupiah terhadap Dolar AS maka return yang akan didapatkan akan semakin tinggi dari return yang diharapkan, sehingga nilai abnormal return akan semakin baik. Begitu pula sebaliknya, saat mata uang domestik melemah, maka investor akan lebih memilih berinvestasi dalam bentuk valas daripada surat berharga seperti saham, karena return yang akan didapatkan dinilai lebih tinggi dengan resiko lebih rendah (Suriyani \& Sudiartha, 2018). Hal ini didukung oleh penelitian (Nidya \& Mawardi, 2018), (Made Satria, 2016), dan (Pujawati et al., 2015) yang menemukan bahwa tingkat nilai tukar berpengaruh signifikan negatif terhadap return saham dan abnormal return. Sementara hasil penelitian ini tidak sejalan dengan (Apriyani et al., 2015) dan (Hidayat et al., 2017) yang menemukan bahwa tingkat nilai tukar berpengaruh positif terhadap return saham.

\section{Pengaruh ROE terhadap Abnormal Return}

Hasil uji t menunjukkan ROE mempunyai hubungan yang positif tetapi tidak berpengaruh signifikan terhadap abnormal return. Tidak signifikannya pengaruh ROE terhadap abnormal return dapat disebabkan oleh data ROE perusahaan pada penelitian ini tidak terdistribusi dengan baik, terdapat kesenjangan yang besar antar nilai minimum dan maksimum, sehingga investor kurang dapat menggunakan data tersebut sebagai informasi dasar untuk mengambil keputusan berinvestasi. Walaupun tidak berpengaruh secara signifikan, ROE masih mempunyai hubungan positif terhadap abnormal return yang tercermin dari nilai positif pada koefisien regresi. ROE adalah sebuah rasio profitabilitas yang mengukur seberapa efektif perusahaan menggunakan modalnya dalam memperoleh laba. Profitabilitas digunakan sebagai salah satu acuan dalam menilai kinerja perusahaan. Semakin tinggi profit yang dihasilkan, maka kinerja perusahaan dinilai makin membaik. Apabila profit yang dihasilkan meningkat, maka akan semakin banyak investor yang tertarik menanamkan dananya pada saham tersebut, sehingga permintaan saham akan meningkat. Jika permintaan meningkat, maka harga saham akan meingkat sehingga return aktual yang akan diterima oleh investor akan melebihi return harapan dan nilai abnormal return akan membaik. Hal ini sejalan dengan penelitian yang dilakukan oleh (Satria \& Norita, 2017) dan (Fauziah, 2017), mereka juga menemukan bahwa ROE berpengaruh positif tidak signifikan terhadap abnormal return saham.

\section{Pengaruh Tidak Langsung Variabel Makroekonomi terhadap Abnormal Return Saham melalui ROE}

Dalam model ini ROE tidak mampu memediasi pengaruh variabel inflasi terhadap abnormal return. Hal ini dapat disebabkan oleh beberapa faktor seperti saat periode pengamatan terjadi kenaikan harga BBM sehingga beban yang ditanggung oleh perusahaan khususnya di bidang trasnportasi akan bertambah. Kenaikan harga BBM juga berimbas kepada naiknya harga-harga yang berada di pasaran sehingga dapat menyebabkan peningkatan pada nilai inflasi suatu negara. Apabila hal itu terjadi, biaya yang akan ditanggung perusahaan akan bertambah dan modal yang digunakan untuk operasional akan semakin besar sehingga dapat menurunkan keuntungan yang akan diterima oleh perusahaan. Apabila keuntungan perusahaan menurun, maka akan memengaruhi nilai ROE yang juga akan mengecil. ROE yang mengecil menunjukkan ketidak efsienan perusahaan dalam memanfaatkan modal yang dimilikinya untuk menghasilkan laba. Hal tersebut dapat mengakibatkan keuntungan yang akan diperoleh investor menurun dan return aktual yang didapatkan juga akan lebih sedikit dari return yang diharapkan, sehingga nilai abnormal return akan menurun.

ROE tidak mampu memediasi pengaruh variabel PDB terhadap abnormal return. Hal ini disebabkan oleh beberapa faktor. Pada saat periode penelitian, nilai PDB cenderung meningkat sehingga pertumbuhan perekonomian akan membaik. Selain itu sektor maritim menjadi salah satu sektor yang mengalami pertumbuhan meningkat selama periode pengamatan (CNBC Indonesia, 2019) sehingga investor akan tertarik untuk berinvestasi dan meningkatkan harga saham. Apabila harga saham meningkat, maka return aktual yang akan didapatkan oleh investor juga akan meningkat. Faktor lain yaitu banyaknya komponen penyusun PDB sehingga nilai PDB tidak selalu dapat mencerminkan 
Norromadani Yuniati, Farizi Rachman, Ratri Wahyuning Purwitasari. Analisa Makro Ekonomi pada Perusahaan pelayaran di Indonesia

secara spesifik keuntungan yang akan didapatkan oleh perusahaan di industri tertentu khususnya industri maritim.

ROE tidak mampu memediasi pengaruh variabel tingkat suku bunga terhadap abnormal return. ROE dianggap dapat memperkirakan tingkat pertumbuhan dividen. Apabila tingkat suku bunga meningkat maka akan menurunkan nilai sekarang dari pendapatan dividen di masa datang, hal ini dapat menurunkan harga saham di pasar modal. Apabila harga terus menurun, investor akan beralih pada instrument investasi lain yang mempunyai resiko yang lebih kecil. Karena harga saham yang menurun, dapat menyebabkan return yang akan diterima oleh investor lebih sedikit dari return yang diharapkan sebelumnya. Apabila hal tersebut terjadi, maka nilai abnormal return akan menurun. Tingkat suku bunga selama periode pengamatan yang cenderung stabil dan menurun juga dapat menjadi penyebab investor masih dapat mentolerir angka tersebut, perusahaan juga tidak terganggu dengan adanya kenaikan tingkat suku bunga bank sentral sehingga kurang dapat mencerminkan nilai ROE yang digunakan untuk mengetahui tingkat keuntungan perusahaan dan return yang akan didapatkan oleh investor berdasar penggunaan modal perusahaan tersebut.

ROE tidak mampu memediasi pengaruh variabel tingkat nilai tukar terhadap abnormal return. Mata uang domestik yang mengalami depresiasi atau berkurang satu-satuan menandakan mata uang domestik tersebut menguat terhadap mata uang asing. Depresiasi nilai tukar mata uang domestik dapat meningkatkan laba yang akan diterima oleh perusahaan karena meningkatkan volume ekspor. Apabila laba meningkat maka ROE juga akan meningkat dan return yang didapatkan oleh investor akan melebihi return yang diharapkan. Sehingga nilai abnormal return akan meningkat.

Selain beberapa faktor dan hubungan yang disebutkan sebelumnya, ketidak berhasilan ROE dalam memediasi hubungan tidak langsung antara makroekonomi secara parsial terhadap abnormal return dapat disebabkan faktor lain. Ditinjau dari hasil statistik deskriptif, nilai rata-rata ROE berada di tingkat negatif yaitu sebesar -1.92 , hal ini menunjukkan kinerja perusahaan pelayaran di Indonesia belum efektif dalam pengelolaan modalnya untuk menghasilkan laba. Keadaan fluktuasi makroekonomi yang tidak menentu juga dapat memengaruhi bertambahnya biaya-biaya operasional yang harus ditanggung oleh perusahaan sehingga keuntungan akan berkurang bahkan dapat mengalami kerugian. Pada hasil statistik deskriptif, data ROE juga tidak berdistribusi dengan baik, salah satu penyebabnya yaitu pemilihan sampe yang kurang representatif yang mengakibatkan data menjadi bias. Data yang bias disebabkan oleh adanya kesenjangan antara nilai minimum dan maksimum pada variabel ROE seperti pada hasil uji statistik deskriptif. Lalu kesalahan dalam pemilihan sampel yang kurang representatif dan memasukkan IPO sebagai salah satu kriteria sehingga perusahaan-perusahaan tersebut belum stabil keadaanya. Tidak stabilnya keadaan perusahaan mengakibatkan asumsi terkait keuntungan dan rasio rasio keuangan akan sulit terukur karena perusahaan tersebut belum likuid. Selain itu hal-hal diluar penelitian seperti kebijakan perusahaan dan target operasional yang tidak dapat dicapai oleh perusahaan, dapat mengakibatkan nilai ROE menjadi kecil. Data yang bias dan rata-rata ROE yang negatif, membuat investor lebih memilih menggunakan rasio-rasio lain dan meninjau faktor eksternal lain sebagai dasar pengambilan keputusan menentukan return dan abnormal return yang akan diterima.

\section{KESIMPULAN DAN SARAN}

Makroekonomi secara parsial tidak berpengaruh secara tidak langsung terhadap abnormal return saham melalui return on equity (ROE) pada perusahaan transportasi laut di Indonesia. Dalam hal ini ROE tidak berhasil menjadi variabel intervening yang menghubungkan antara pengaruh makroekonomi terhadap abnormal return secara tidak langsung. ROE perusahaan transportasi laut dalam sampel penelitian ini tidak "berdistribusi" dengan baik mengakibatkan informasi yang tersampaikan pada pelaku pasar modal menjadi bias, sehingga investor tidak menggunakan informasi tersebut sebagai dasar pengambilan keputusan untuk menentukan jumlah return dan abnormal return yang akan didapatkan. Sehingga hipotesis pada penelitian ini yaitu makro ekenomi secara parsial berpengaruh secara tidak langsung terhadap abnormal return saham melalui return on equity tidak terbukti diterima. Bagi penelitian selanjutnya disarankan untuk menggunakan sampel penelitian yang 
lebih banyak dan representative menggambarkan pasar modal Indonesia, serta menambahkan variabel makro lainnya yang juga mendorong perubahan return saham di pasar modal.

\section{DAFTAR PUSTAKA}

Afifah, N., Fathoni, A., \& Amboningtyas, D. (2017). the Effect of Macroeconomic Factors on Profitability of Stock Returns As Intervening Variables. II(November).

Apriyani, N., Rindayati, W., \& Wiliasih, R. (2015). Analisis Pengaruh Variabel EPS dan Makroekonomi terhadap Return Saham Jakarta Islamic Index Sektor Pertanian. Al-Muzara'ah, 3(1), 44-61. https://doi.org/10.29244/jam.3.1.44-61

Boediono. (2014). Seri Sinopsi Pengantar Ilmu Ekonomi Makro. Daerah Istimewa Yogyakarta: BPFE.

CNBC Indonesia. (2019). Ekonomi Indonesia 2018 Capai Rp 14.837,4 T, Ini Komposisinya. Retrieved from https://www.cnbcindonesia.com/market/20190206140257-17-54058/ekonomiindonesia-2018-capai-rp-148374-t-ini-komposisinya

Debbi Fauziah, U. dan H. P. (2017). Pengaruh Kinerja Keuangan Dan Kebijakan Dividen Terhadap Abnormal Return. JSMBI (Jurnal Sains Manajemen Dan Bisnis Indonesia), 7(1), 58-76.

Hidaya Tri Afiyati. (2016). Pengaruh Inflasi , Bi Rate Dan Nilai Tukar Terhadap Return Saham ( Studi Pada Perusahaan Subsektor Food \& Beverages Yang Terdaftar Di Bursa Efek Indonesia Periode 2013-2016 ). Jurnal Administrasi Bisnis, 61(2), 144-152.

Hidayat, L. R., Setyadi, D., \& Azis, M. (2017). Influence of inflation and interest rate and rupiah exchange rate and money supply to stock return. Forum Ekonomi, 19(2), 148-154.

Ishomuddin. (2010). Analisis Pengaruh Variabel Makroekonomi Dalam dan Luar Negeri terhadap Indeks Harga Saham Gabungan di BEI periode 1999. Semarang: Universitas Diponegoro.

Jumiati, H. (2019). Analisis Pengaruh Faktor Fundamental Perusahaan Dan Kondisi Makro Ekonomi Terhadap Abnormal Return Perusahaan Industri Pertambangan Di Bei (Bursa Efek Indonesia). E-Jra, 8(10), 68-81.

Kementerian Keuangan Republik Indonesia. (n.d.). Ekonomi Makro. Retrieved from https://klc.kemenkeu.go.id/category/ekonomi/ekonomi-makro/

Kewal, S. S. (2012). Pengaruh Inflasi, Suku Bunga, Kurs, dan Pertumbuhan PDB terhadap Indeks Harga Saham Gabungan. Jurnal Economica, 8(1).

Kurniasari, W., Wiratno, A., \& Yusuf, M. (2018). Pengaruh Inflasi Dan Suku Bunga Terhadap Return Saham Dengan Profitabilitas Sebagai Variabel Intervening Di Perbankan Yang Terdaftar Di Bursa Efek Indonesia Tahun 2013-2015. Journal of Accounting Science, 2(1), 67. https://doi.org/10.21070/jas.v2i1.1216

Made Satria, W. A. dan L. K. S. (2016). Pengaruh Tingkat Suku Bunga, Tingkat Inflasi, Nilai Kurs Rupiah Dan Produk Domestik Bruto Terhadap Return Saham. E-Jurnal Manajemen Unud, 5(6), 3392-3420.

Madura, J. (2008). International Financial Management (9th ed.). United States of America: Thomson South-Western, a part of The Thomson Corporation.

Mankiw, N. G. (2014). Pengantar Ekonomi Makro. Jakarta: Salemba Empat. 
Norromadani Yuniati, Farizi Rachman, Ratri Wahyuning Purwitasari. Analisa Makro Ekonomi pada Perusahaan pelayaran di Indonesia

Mayfi, F. dan D. R. (2014). Analisis Pengaruh Faktor Internal dan Eksternal Perusahaan terhadap Return Saham. Jurnal MIX, 4(3), 348-362.

Nidya, A. T., \& Mawardi, I. (2018). Analisis Jalur Faktor Makroekonomi Terhadap Return Saham Syariah. Jurnal Ekonomi Syariah Teori Dan Terapan, 5, 873-888.

Pujawati, P. E., Wiksuana, I. G. B., Gede, L., \& Artini, S. (2015). Dengan Profitabilitas Sebagai Variabel Intervening Fakultas Ekonomi dan Bisnis, Universitas Udayana ( Unud ), Bali, IndonesiaEmail: eka_pj18@yahoo.co.id Peranan penting pasar modal bagi pihak emiten sebagi tempat untuk mendapatkan sumber dana sedangka. 04, 220-242.

Putra, I.N.S.A, dan I.G.A.N, B. (2016). Pengaruh Produk Domestik Bruto Negara Indonesia, Ukuran Perusahaan, dan Dividen Payout Ratio pada Return Saham. E-Jurnal Manajemen Unud, 6(4), $2105-2132$.

Satria, P. W., \& Norita, D. (2017). Analisis Faktor Fundamental Serta Faktor Makroekonomi Dan Pengaruhnya Terhadap Return Saham (Studi Pada Perusahaan Telekomunikasi Yang Terdaftar Di Bursa Efek Indonesia Periode 2011-2015). E-Proceeding of Management, 4(1), 187-194.

Sinaga, A., \& Triaryati, N. (2014). Pengaruh Faktor Fundamental Dan Ekonomi Makro Terhadap Harga Saham. E-Jurnal Manajemen Universitas Udayana, 3(5), 250635.

Sukirno, S. (2010). Makro Ekonomi. Jakarta: Raya Grasindo Persada.

Suriyani, N. K., \& Sudiartha, G. M. (2018). Pengaruh Tingkat Suku Bunga, Inflasi Dan Nilai Tukar Terhadap Return Saham Di Bursa Efek Indonesia. E-Jurnal Manajemen Universitas Udayana, 7(6), 3172. https://doi.org/10.24843/EJMUNUD.2018.v07.i06.p12

Tandelilin, E. (2010). Portofolio dan Investasi (7th ed.). Daerah Istimewa Yogyakarta: PT. Kanisius.

Wahyuningsih, E., Andini, R., \& Suprijanto, A. (2018). Pengaruh Tingkat Suku Bunga Dan Inflasi Terhadap Return Saham Dengan Nilai Tukar Rupiah Sebagai Variabel Interberning (Studi Kasus pada PT Astra International Tbk Periode 2011-2015 ) ABSTRACT This research aims to examine the level of interest rates and i. Journal Of Accounting, 1-19. 